IdeAs in Ecqlagy ANd Evalution 11: 90-95, 2018

doi:10.24908/iee.2018.11.13.e

(C) 2018 The Author

Received 27 December 2018; Accepted 27 December 2018

\title{
Editarial
}

\section{Meet Homo absurdus - the only creature that refuses to be what it is}

\section{Lonnie Aarssen}

Lonnie Aarssen (aarssenl@queensu.ca), Department of Biology, Queen’s University, Kingston, ON, Canada, K7L $3 N 6$

Homo sapiens sapiens ('wise human') may describe a distant human ancestor, but if it ever did, the name no longer suits us. As Cribb (2011) put it, "An animal that imperils its own future and that of most other life forms and ecosystems does not merit a single 'sapiens', let alone the two we now bear." Some have suggested alternative species names based on predictions for where humanity appears to be headed in the $21^{\text {st }}$ century: Homo deus (Havari 2016) and Homo sentiens (Tegmark 2017) describe future, 'upgraded' versions of humans with technologies like artificial intelligence, and prospects for its integration with consciousness. Other naming suggestions offer species descriptions that are ostensibly more accurate representations of what contemporary humanity has become: Homo consumericus (Saad 2011) underlines how our evolved psychology has been conspicuously shaped by a (mostly unwise) consuming instinct, and Homo prospectus (Seligman et al. 2016) represents our uniquely human capacity to imagine alternatives projected into the distant future.

Here I offer another suggestion - not a new name for an old species, but a new name for a derived phenospecies, one that possibly evolved from an ancestral 'wise' human, but at some point became what we are today: Homo absurdus-human that spends its whole life trying to convince itself that its existence is not absurd. ${ }^{1}$ As Albert Camus (1956) put it, "Man is the only creature who refuses to be what he is." Dobzhansky (1967), I think, describes the critical juncture in the evolutionary line to Homo absurdus: "A being who knows that he will die arose from ancestors who did not know." Becker (1971) elaborates:
"The world of human aspiration is largely fictitious, and if we do not understand this, we understand nothing about man. ...If you reveal the fictional nature of culture you deprive life of its heroic meaning because the only way one can function as a hero is within the symbolic fiction. If you strip away the fiction man is reduced to his basic physical existence-he becomes an animal like any other animal. And this is a regression that is no longer possible for him. The tragic bind that man is peculiarly in-the basic paradox of his existence-is that unlike other animals he has an awareness of himself as a unique individual on the one hand; and on the other hand he is the only animal in nature who knows he will die."

The work of Becker (1973) subsequently inspired 'terror management theory', involving a large body of research in social psychology showing that mortality priming (reminders of death) routinely evokes a wide range of behaviours associated with cultural worldview defense and esteem striving (Burke et al. 2010, Solomon et al. 2015).

Early humans therefore at some point understood that their bodies unavoidably die. And this mortality salience was-possibly later, but ultimately-accompanied by mortality anxiety, rooted presumably in the core instinct for survival that we share with other animals. But the evolution of human minds eventually included two additional components that became diagnostic in the emergence of Homo absurdus: (i) a deeply ingrained

\footnotetext{
${ }^{1}$ Absurdity is when there is “... a conspicuous discrepancy between pretension or aspiration and reality” (Nagel 1971).
} 
sentiment that one has a 'mental life' (self-identity, esteem, psyche, ego, personhood) that exists apart from 'material life' (the physical body); and (ii) an incessant uncertainty about 'self' permanence, manifesting as 'selfimpermanence anxiety' - a chronic fear that, in bringing eventual material death, time may inevitably also annihilate all that 'I' do, and all that 'I' am, and that soon therefore, it may be as though 'I' never existed at all. Nowhere is this diagnosis more eloquently reflected than in this passage from $19^{\text {th }}$ Century English essayist, William Hazlitt (1827):

"To see the golden sun and the azure sky, the outstretched ocean, to walk upon the green earth, and to be lord of a thousand creatures, to look down giddy precipices or over distant flowery vales, to see the world spread out under one's finger in a map, to bring the stars near, to view the smallest insects in a microscope, to read history, and witness the revolutions of empires and the succession of generations, ...to traverse desert wildernesses, to listen to the midnight choir, to visit lighted halls, or plunge into the dungeon's gloom, or sit in crowded theatres and see life itself mocked, to feel heat and cold, pleasure and pain, right and wrong, truth and falsehood, to study the works of art and refine the sense of beauty to agony, to worship fame and to dream of immortality, to have read Shakespeare and belong to the same species as Sir Isaac Newton; to be and to do all this, and then in a moment to be nothing, to have it all snatched from one like a juggler's ball or a phantasmagoria; there is something revolting and incredible to sense in the transition, and no wonder that, aided by youth and warm blood, and the flush of enthusiasm, the mind contrives for a long time to reject it with disdain and loathing as a monstrous and improbable fiction."

\section{Wherefore absurdity?}

Clearly our ancestors inherited strong motivations that prolonged survival, and so-since evolving mortality salience-have long been uneasy with the prospect of material death, but they essentially acquiesced to its inevitability. For most modern minds, however, annihilation of one's 'mental life' is a prospect largely unimaginable, unacceptable, or categorically denied. This curse of consciousness is the fundamental human predicament of Homo absurdus. Somehow, our ancestors evolved to become the only creature afflicted with unrelenting obsession to find 'purpose' and 'meaning' in terms of suppositions and hopes/beliefs about domains for extension of 'self' beyond mortal existence. As Maeterlinck (1913) put it, "Here is the core of the enigma: This little consciousness, this feeling of a specific me, demands that it accompany us into infinity" (quoted from Choron 1964). But how could evolution produce such a predicament-such entrenched absurdity? How could natural selection shape a mind determined to "...believe passionately in the palpably not true...the chief occupation of mankind" (Mencken 1949), and at the same time plagued with perpetual uncertainty of its own alignment? A mind so easily deluded and riddled with angst would seem to compromise, not reward, reproductive success.

The answer to this conundrum, I suggest, involves three postulates, representing three stages in the lineage to Homo absurdus:

(i) Time- and self-awareness/consciousness evolved in our ancestors with fine-tuned precision because of genetic fitness benefits that emerged from these cognitive skills-benefits that turned out to be 'game-changers': ability to anticipate and plan for the future; ability to attribute mental states - thoughts, emotions, intentions, perspectives, knowledge - to oneself, and to distinguish these from the particular mental states of others, and hence ability to predict the behaviour of others and to gauge how one might be perceived by others; capacity for empathy, moral instinct, and social learning, and hence to be experts at imitation, teaching, cooperation, negotiation, and teamwork, and at the same time masters of manipulation, gossip, deception, cheating, and lying - all enabled by a brain wired to process complex language. In our degree of endowment for all of these skills, our ancestors left all other hominids 'in the dust'.

(ii) This cognitive evolution at some point, became associated with a visceral conviction that 'mental life' and 'material life' are distinct and exist separately. And this was followed (possibly shortly after) by an intrinsic worry that, like material life, mental life - the 'self' - is also impermanent. All of this may have converged, I suggest, after our ancestors had already incurred (for a period of some time) many of the above fitness benefits of consciousness (Aarssen 2017). Self-impermanence anxiety (like mortality anxiety) seems to be rooted in the primal fear connected with 'survival drive' - the instinct that promotes continued life for the material body- that we inherited from proto-human ancestors. Selfimpermanence anxiety then was probably, at least in part, an inevitable consequence of self-consciousness - as a 'misfire' of material survival drive (Aarssen 2015). But it seems reasonable to suppose that any attendant fitness cost associated with this emotional burden would have been largely out-weighed by the very substantial fitness benefits of self-consciousness.

(iii) In the final stage approaching Homo absurdus, natural selection favoured novel and uniquely human fundamental drives that served to buffer the worry of self- 
impermanence, thus minimizing its potential fitness costs. There are two main kinds: 'escape from self', and 'extension of self' (Aarssen 2015). Both are reflected in a prescient passage from $19^{\text {th }}$ Century Russian author, Leo Tolstoy (1872): "For man to be able to live he must either not see the infinite, or have such an explanation of the meaning of life as will connect the finite with the infinite."

\section{Delusion, distraction, and oblivion}

'Extension of self' ('connecting the finite with the infinite') involves what I call 'Legacy Drive' (Aarssen 2010 , 2015) - a deeply ingrained susceptibility to delusions of being able to leave something appreciable about one's identity/personhood (an 'extension of self') that will endure beyond mortal existence. Delusions of legacy then provide many with a sense of 'meaning'. They involve one or more of three principal domains:

(i) through parenthood-projecting a pedigree of one's selfhood (i.e. ideas, values, beliefs, attitudes, character, conscience, pride, will, intellect, personality, knowledge, skills, and virtues) by intentionally shaping the selfhood of offspring and grand-offspring to mirror one's own;

(ii) through accomplishment - creating memes of one's personhood - a kind of symbolic immortality - in the minds of others by earning recognition/admiration/status/ prestige from deeds/achievements;

(iii) through religiosity-belief in afterlife transcendence, involving faith in theism/deism/spirituality.

For those less prone to these delusions, there is 'escape from self'-Tolstoy's 'not seeing the infinite'. Most commonly this is achieved through distractions, deployed through what I call 'Leisure Drive' (Aarssen 2010, 2015) - a deeply ingrained disposition to be easily drawn to free-time indulgence in opportunities for enjoyment. Typically, these involve motivations that hack into pleasure modules/triggers (e.g. serotonin/oxytocin/ endorphin/dopamine rushes) that have deep evolutionary roots associated with meeting core needs (e.g. for survival, social affiliation, sex, endearment, kinship) that rewarded ancestral gene transmission success. Domains of Leisure Drive are manifested in many modern cultural norms and products for pleasure-inducing distraction/ 'escape'-like toys, stories, games, aesthetics, social entertainment, consumerism, humour, snacking, recreational sex, exercise, yoga, meditation, inebriation and psychedelics. Alternatively for some, distraction may be secured through intentional infliction of physical pain (masochism) (Beaumeister 1989). Both pleasure and pain can provide the quintessential element of escape from self-arresting the mind firmly in the present, thus temporarily but effectively shielding it from worries of the future (where self-impermanence in eternity resides), as well as regrets of the past.
Note however that effective domains of escape from self need not be particularly exhilarating. In many cases, they may be pleasant enough (e.g. restfully reclining on the sofa while mindlessly flicking through TV channels or scrolling through Facebook pages on a smartphone) simply because they bring a welcome solace: diversion from the agonies of existence, and of the human predicament in particular-the curse of consciousness. The role of leisure here then is, most essentially, palliative. It delivers respite - a vehicle for periodic escape-from the exasperating human obsession of needing to be convinced that one's existence is not absurd. For some/many, placing the mind firmly in the present may be accomplished by simply keeping busy with purposeful toil, for example in helping others in need, even if it involves mundane routine (Baumeister et al. 2013). In other words, if you can't keep calm, keep busy. As Hoffer (1976) put it, "A busy life is the nearest thing to a purposeful life." And famously, from Blaise Pascal (1670): "All of humanity's problems stem from man's inability to sit quietly in a room alone." This is poignantly captured in a rumination from Carl Jung (1939, Wirklichkeit der Seele, quoted from Choron 1964).

\footnotetext{
“... an old man experiences a secret shudder, nay even death fear at the thought that his reasonable life expectancy now amounts to only so and so many years, one is painfully reminded of certain emotions in one's own breast: one looks the other way and tries to change the subject ..." [But] "When one is alone and it is night and so dark and quiet that one does not see or hear anything but the thoughts that add and subtract the years of one's life, and the long sequence of those unpleasant facts, which prove cruelly how far the hand of the clock has advanced, and the slow and uncheckable approach of that dark wall, which threatens to swallow up irretrievably all I love, desire, possess, hope, and strive for, then all the wise dicta go into hiding and fear descends upon the sleepless like a choking blanket."
}

Is there 'meaning' to be found in these domains for 'escape from self'? Perhaps not; maybe they are just about being "... distracted from distraction by distraction, filled with fancies and empty of meaning" (Eliot 1943). But some might describe these distractions as providing a different sense of meaning - one based not in striving for meritable legacy, but rather, in striving for an untroubled mind. In other words, a central purpose in life, for some, may lie in maintaining just (and simply) that-an untroubled mind. And if this can be delivered through the intentional deployment of triggers for pleasure (or pain), or opportunities for busyness, the resulting happiness 
then indeed evokes a sense of meaning. Of course, this requires regular and repeated deployment; it only works if we keep coming back for more. Importantly then, the act of 'striving' here is just as true for those whose remedies involve adherence to mindfulness and meditation as it is for those who are drawn more to other (perhaps less edifying) distractions, like toys, stories, games, and good times with friends at the pub-or just keeping busy. Importantly, I suggest, our predecessors who were good at keeping busy probably left more descendants generally than those who were good at keeping calm..

Finally, for those who might find distraction inadequate for 'escape from self', there is of course a more assured option: oblivion (unconsciousness), available through induced sleep, sedation, anesthesia, hypnosis, intoxication, narcosis, or (ultimately) suicide (Beaumeister 1990). At this level, it is perhaps not difficult to understand how the agonies of existence might persuade some that it would be "better never to have been" (Benatar 2006).

\section{Minds on runaway selection}

The delusions of Legacy Drive and the distractions of Leisure Drive are both represented in the well-known adage: 'Dream as if you'll live forever; live as if you'll die today' - and summarized in the popular slogan, 'Work hard, play hard'. The latter can be traced to the early $19^{\text {th }}$ Century, in Newnham (1827):

\begin{abstract}
"Whatever is done, it should be habitually done with earnestness; in every pursuit, exertion should be employed; work hard and play hard; always recollecting that quiescence, the stillness of inactivity is destructive to the mental welfare, and approaches very nearly to the winter of the faculties, the torpor of an hibernating animal, the unprotected state of sleep, or the complete cessation of life."
\end{abstract}

These self-impermanence anxiety buffers enabled minds that could function mostly unhindered by troubling thoughts of possibly losing one's 'mental life'-and hence minds thinking only infrequently about death (loss of 'material life'). By helping to mitigate the curse of consciousness, selection for strong Legacy and Leisure Drives thus rewarded ancestral gene transmission success, and of course conspicuously so for those ancestors drawn to parenthood as a domain for legacy. Ironically then, as it turned out, self-impermanence anxiety - by motivating ancestors to produce offspringcould actually promote (rather than limit) fitness (Aarssen 2010). The descendants in turn became Homo absurdus, spending their whole lives trying to convince themselves that their existence is not absurd-commonly with success, by using 'extension of self' delusions through accomplishment and religion in addition to parenthood, and/or using various distractions for 'escape from self'.

Importantly however, our ancestors were never really perfectly or permanently convinced; self-impermanence uncertainty/anxiety always lurked stubbornly beneath the surface. And so this long history of selection, I suggest, has ramped up in momentum like a 'runaway train'. As Nettle (2005) put it, "The idea of happiness has done its job if it has kept us trying. In other words, evolution hasn't set us up for the attainment of happiness, merely its pursuit. ... We don't necessarily learn from experience that this is a trick, because we are not necessarily designed to do so". And unfortunately, this obsession brought with it a cultural evolution that fueled the frenzied and relentless 'march of progress' that we call civilization.

Human motivations did not evolve to deliver us untroubled minds - only fitness. It was the striving for an untroubled mind that delivered fitness, and this has created ideal conditions for a kind of 'runaway selection'. Our lives resemble the lives of chimpanzees more than any other animal. They have a rudimental theory of mind and capacity for culture through social learning. But as Sterelny (2012) put it, chimps "...live in a world as they find it", while humans "...live in a world as they make it." And we have made it mostly a world of delusions for chasing legacy, and a world of distractions for chasing leisure - and this has made a world of environmental catastrophes that are annihilating other species and their habitats at a rate not seen since the extinction of dinosaurs (Gilbert 2018).

In an interesting commentary, Miller (2006) considers that the reason why we have not yet made contact with other advanced extraterrestrial life is perhaps not because we are alone in the galaxy, but because evolved technical intelligence (like ours) has some deep tendency to be selflimiting, even self-exterminating. More generally, I suggest that runaway selection for Leisure and Legacy Drives - in response to runaway selection for more acute self-impermanence anxiety-has generated two dire consequences for humanity: (i) a civilization now on the verge of collapse (Ripple et al. 2017, Tollefson 2018); and (ii) the ramped-up demands of these drives (resulting from biological evolution) are starting to exceed the supply rate of available domains (generated by cultural evolution) for satisfying them (Figure 1). In other words, the effective 'shelf lives' for newer and more convincing distractions (for escape from self) and delusions (for extension of self) become shorter and shorter, while Leisure and Legacy Drives become stronger and stronger. As these intensities accelerate, therefore, civilization moves faster and faster to collapse. And at the same time, incidences of anxiety disorders, depression and suicide escalate (Leary 2007, Curtin et al. 2016, 


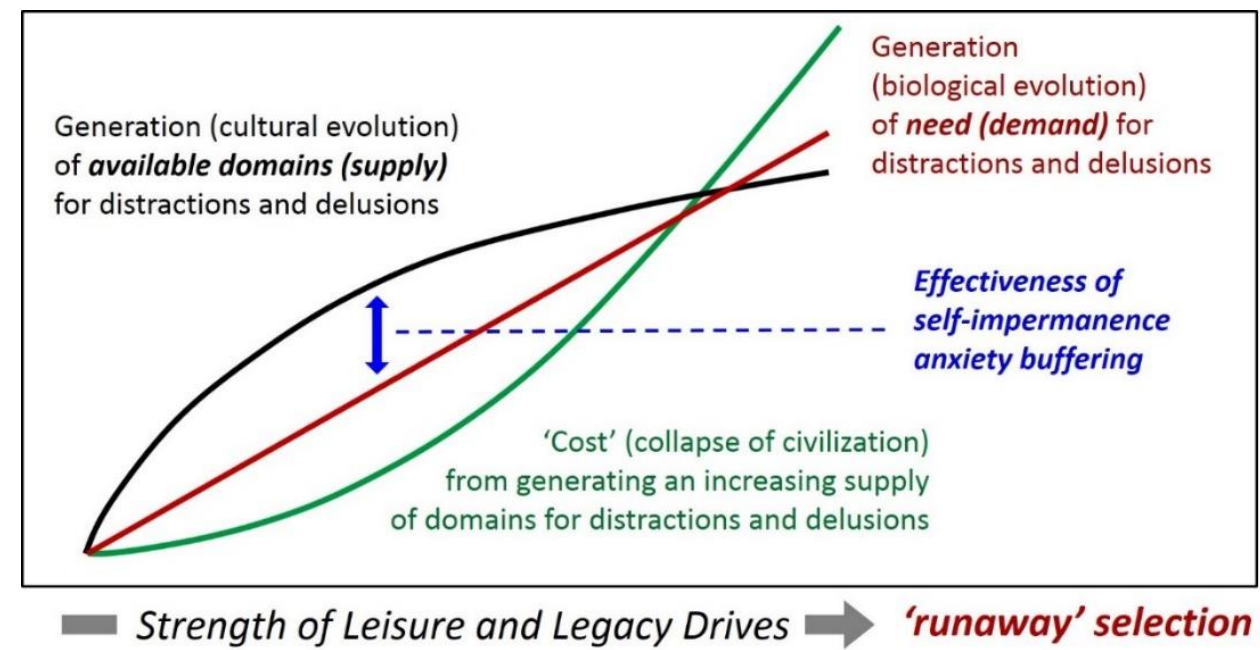

Figure 1. Effectiveness of self-impermanence anxiety buffering requires that available supply of domains for distractions and delusions (black line) is able to keep up with the increasing need (demand) for distractions and delusions (red line) generated by 'runaway' selection for more acute self-impermanence anxiety, and hence for stronger and stronger impulses for 'escape from self' (Leisure Drive) and 'extension of self' (Legacy Drive). Civilization therefore races faster and faster toward collapse (green line), because of the escalating negative impact on ecosystem services resulting from the escalating cultural evolution of products and institutions designed for delivering distractions and delusions.

Nock 2016) as it becomes harder and harder for cultural products and institutions to provide adequate buffering to keep up with and meet an ever increasing demand for distractions and delusions-including distractions to buffer the mounting anxiety from living in a collapsing civilization.

\section{Where to from here?}

Where is all of this likely to lead us? How can we manage our human predicament, now that we are Homo absurdus? Arriving at effective solutions to a problem usually requires understanding the cause, not just treating the symptoms. Accordingly, I have suggested that a new model for cultural evolution might come to our rescue involving a kind of 'biosocial management', based on facilitating and implementing a deeper and more broadly public understanding of (and empathy for) the evolutionary roots of human motivations, especially those associated with our responses to self-impermanence anxiety (Aarssen 2015). Successfully abating and regulating the frenetic drive to convince ourselves that our existence is not absurd requires that we realize why we are so compelled to do so.

Failing this, perhaps through transhumanism-with technologies of nanobiology, robotics, gene editing, and interfacing computer chips-we might engineer an 'upgraded' version of humanity, complete with a mind permanently hard-wired/programmed to be untroubled, free of self-impermanence anxiety (among other 'defects', presumably).

Alternatively, if routine natural selection continues to have sway, perhaps our distant descendants will persist and flourish by evolving a future mind more like the minds of other animals, and of the earliest humans - by becoming another phenospecies: Homo retrovertushuman without comprehension of absurd existence; with a mind completely indifferent to the fact that time inevitably annihilates all that one does and all that one is, and that soon it will be as though one never existed at all.

I think I would rather that cultural evolution somehow come to our rescue.

\section{References}

Aarssen, L.W. 2010. Darwinism and meaning. Biological Theory 5: 296-311. CrossRef

Aarssen, L.W. 2015. What Are We? Exploring the Evolutionary Roots of Our Future. Kingston: Queen's University. http://www.campusebookstore.com/E Books/Book.aspx?ID=9657344\&bookseller_id=5

Aarssen, L.W. 2017. The sapiens advantage. Ideas in Ecology and Evolution 10: 6-11. CrossRef

Becker, E. 1971. The Birth and Death of Meaning: An Interdisciplinary Perspective on the Problem of Man, 2nd Edn. New York: The Free Press. 
Becker, E. 1973. The Denial of Death. New York: Simon and Schuster.

Benatar, D. 2006. Better Never to Have Been: The Harm of Coming Into Existence. Oxford: Clarendon Press. CrossRef

Baumeister, R.F. 1989. Masochism and the Self. Mahwah, NJ: Lawrence Erlbaum Associates.

Baumeister, R.F. 1990. Suicide as escape from self. Psychological Review 97: 90-113. CrossRef

Baumeister, R.F., Vohs, K.D., Aaker, J.L., and E.N. Garbinsky. 2013 Some key differences between a happy life and a meaningful life. The Journal of Positive Psychology 8: 505-516. CrossRef

Burke, B.L., Martens, A., and E.H. Faucher. 2010. Two decades of terror management theory: A metaanalysis of mortality salience research. Personality and Social Psychology Review 14: 155-195. CrossRef

Camus, A. 1956. The Rebel. New York: Knopf.

Choron, J. 1964. Modern Man and Mortality. New York: The Macmillan Company.

Cribb, J. 2011. New name needed for unwise Homo? Nature 476: 282. CrossRef

Curtin, S.C, Warner, M., Hedegaard, H. 2016. Increase in suicide in the United States, 1999-2014. NCHS data brief, no 241. Hyattsville, MD: National Center for Health Statistics.

Dobzhansky, T. 1967. The Biology of Ultimate Concern. New York: The New American Library.

Eliot, T.S. 1943. Four Quartets. New York: Harcourt.

Gilbert, N. 2018. Top UN panel paints bleak picture of world's ecosystems. Nature https://www.nature.com/ articles/d41586-018-03891-1

Harari, W.N. 2016. Homo Deus: A Brief History of Tomorrow. Toronto: Signal Books.

Hazlitt, W. 1827. On The Feeling of Immortality in Youth. First published in the Monthly Magazine, March, 1827. Reproduced in Howe, P.P. (Ed.). 1934. The Complete Works of William Hazlitt, Vol. XVII. London: J.M. Dent \& Sons.

Hoffer, E. 1976. The Ordeal of Change. Cutchogue: Buccaneer Books.

Maeterlinck, M. 1913. La Mort. Paris: BibliothèqueCharpentier.

Mencken, H.L. 1949. A Mencken Chrestomathy. New York: Knopf.

Leary, M.R. 2007. The Curse of Self: Self-Awareness, Egotism, and the Quality of Human Life. New York: Oxford University Press.

Miller, G. 2006. Runaway consumerism explains the Fermi Paradox. Edge: The World Question Center. http://www.edge.org/q2006/q06_9.html\#miller

Nagel, T. 1971. The Absurd. The Journal of Philosophy 68: 716-727. CrossRef

Nettle. D. 2005. Happiness: The Science Behind Your Smile. Oxford University Press, Oxford.
Newnham, W. 1827. The Principles of Physical, Intellectual, Moral, and Religious Education, Volume 2. London: J. Hatchard and Son.

Nock, M.K. 2016. Recent and needed advances in the understanding, prediction, and prevention of suicidal behavior. Anxiety and Depression 33:460-463. CrossRef

Pascal, B. 1670. Pensées. English translation: Krailsheimer, A.J. (1995) London: Penguin Books.

Ripple, W.J. et al. 2017. World scientists' warning to humanity: A second notice. BioScience 67: 10261028. CrossRef

Saad, G. 2011. The Consuming Instinct: What Juicy Burgers, Ferraris, Pornography, and Gift Giving Reveal about Human Nature. New York: Prometheus Books.

Seligman, M.E.P., Railton, P., Baumeister, R.F. and C. Sripada 2016. Homo Prospectus. New York: Oxford.

Solomon, S., Greenberg, J. and T. Pyszczynski. 2015. The Worm at the Core: On the Role of Death in Life. New York: Random House.

Sterelny, K. 2012. The Evolved Apprentice: How Evolution Made Humans Unique. Cambridge: MIT Press. CrossRef

Tegmark, M. 2017. Life 3.0: Being Human in the Age of Artificial Intelligence. New York: Knopf.

Tollefson, J. 2018. Limiting warming to $1.5^{\circ}$ Celsius will require drastic action, IPCC Says: Humanity has a limited window to avoid the more dire effects of climate change, according to a new climate report. https://www.scientificamerican.com/article/limitingwarming-to-1-5-celsius-will-require-drastic-actionipcc-says/

Tolstoy, L. 1872. A confession. Unabridged Dover (2005) republication of the Aylmer Maude (1921) translation. London: Oxford University Press. 